DOI: $10.2478 / \mathrm{adms}-2021-0005$

\author{
A. Czupryński ${ }^{1 *}$, C. Mele ${ }^{2}$ \\ ${ }^{1}$ Silesian University of Technology, Faculty of Mechanical Engineering, Department of \\ Welding Engineering, ul. Konarskiego 18A, 44-100 Gliwice, Poland \\ ${ }^{2}$ Dipartimento di Ingegneria dell'Innovazione, Universitàdel Salento, Via per Monteroni, \\ Lecce 73100, Italy \\ *artur.czuprynski@polsl.pl
}

\title{
PROPERTIES OF FLAME SPRAYING COATINGS REINFORCED WITH PARTICLES OF CARBON NANOTUBES
}

\begin{abstract}
The article presents the results of the preliminary research of tribological properties of flame sprayed nickel and aluminum coatings reinforced with carbon nanotubes made on the structural steel S235J0 substrate. The carbon material - carbon nanotubes Nanocyl NC 7000 (0.5 wt.\% and $1 \mathrm{wt} \%$ ) was used for structural reinforcement. The properties evaluation was made by the use of optical microscopy, scanning electron microscopy, Raman spectroscopy, microhardness measurements, and by means of abrasion and erosion resistance laboratory tests. The obtained results were compared with pure nickel powder coatings $2 \mathrm{~N} 5$ (Ni 99.5\%) and with pure aluminum powder coatings (EN AW 1000 series). It was proved that the flame spraying of nickel and aluminum coatings reinforced with particles carbonaceous material can be an effective alternative for other more advanced surfacing technology. The preliminary test results will be successively extended by further experiments to contribute in the near future to develop innovative technologies, that can be implemented in the aviation industry and the automotive. The presented research is a continuation of the work previously published.
\end{abstract}

Keywords: powder flame spraying; coating; nickel; aluminum; carbon nanotubes; abrasive wear resistance; erosion wear resistance

\section{INTRODUCTION}

Everybody in the modern world expects from material engineering scientists to develop ever lighter and more durable materials which would meet the high strength and quality requirements set for innovative constructions made by the automotive and aerospace industries [1-3]. Where weight reduction with consistent stability plays a major role, modern materials are capturing even more applications. The use of lightweight and durable materials becomes a necessity since global oil resources are constantly declining, and renewable energy sources are not yet effective enough. Depending on the needs of this type of materials may take different form, shape, and size, which is highly desirable in car, aircraft, and space vehicle production. Their usage has many benefits, such as lower fuel consumption, higher load capacity, speed, and easier maintenance by reducing the number of elements [4-6]. Dynamic advances in technology development, especially in the field of advanced production 
technologies led to the development of metal-matrix composites (MMC) [7,8]. The composites of this type achieve high strength and ductility thanks to the metallic matrix, while the stiffness is provided by the reinforcement, which consists of particles-perchance fibersmetallic or ceramic with high stiffness. Nickel and aluminum-based metal matrix composites are a very attractive material for constructions, characterized by high tribological and mechanical properties, effectively combined with a very advantageous strength-to-density ratio. The utilization properties of these composites depend on the type, size, and volume fraction of particles of a reinforcing phase, and on the choice of the matrix type and the method of fabrication. The microstructure of these materials consists of soft matrix and hard phases which provides the increase in abrasion resistance also at high temperatures. Metalmatrix composites can be designed to have specific properties, such as low thermal expansion coefficient and high thermal conductivity. Therefore, these materials are suitable for use in the applications for installation of electronic microcircuits. Nowadays, metal-matrix composite materials are widely used in the aviation and the automotive industry $[9,10]$. In recent years, several studies have been carried out using CNT carbon nanotubes as reinforcement of various materials: polymers, ceramics, and metals, with most of the research involving polymer composites [11,12], ceramic composites in second place [13,14], and only recently published several papers on composites with metallic matrix reinforced with carbon nanotubes (CNT) $[15,16]$. This is quite surprising because most of the construction materials used in the contemporary world are metals. Publications on this topic concern various aspects such as fabrication [17-20], microstructure [21,22], modelling of mechanical properties and the chemical interaction between carbon nanotubes (CNTs) and metals [9,23-25]. Nanotechnology had a strong influence on the direction of the research in the field of surface engineering and related production technology of surface layers and coatings [26,27]. Nowadays, it is possible to use thermal spraying methods for producing not only conventional tribological coatings with specific frictional characteristics (high or low coefficient of friction) and resistance to wear, erosion or corrosion [28-32]. They are also used for producing coatings with unprecedented properties, often intended for special applications and working in difficult conditions, e.g., nanocomposite coatings with high hardness and high resistance to dynamic loads, coatings with frictional characteristics that adapt to changing operating conditions (temperature, humidity), thermal barrier coatings or biocompatible coatings $[33,34]$. High-quality nanostructure coatings are often used on parts of car engines made of aluminum alloys, on copper alloys intended for propellers of vessels, or on heat-resistant intermetals. In surface engineering technology, the implementation of this type of coating is possible by thermal spraying, where the applied metallic layer is bonded to the substrate adhesively or mechanically without melting the base material [33]. The main advantage of thermal spraying technology is the minimal thermal influence on the sprayed materials. Even in the case of laser cladding technologies characterized by the lowest heat input of all the cladding technologies, the substrate material is always partially melted, as well as the additional material, usually in a form of metallic or composite powder. The carbon nanotubes, due to the small dimensions, have very low heat capacity. Additionally, they have high absorption of laser radiation. For this reason, the introduction of carbon nanotubes into the melt pool during laser cladding is basically impossible, because of overheating and decomposition of nanotubes [35-38]. The pioneers in the field of thermal spraying processes for composite coatings of aluminum-carbon nanotubes (CNT) were a research group from Florida International University, who successfully deposited carbon nanotubes in the Al-Si matrix in the powder plasma spraying process [39]. Bakshi et al. [15] made multi-layer nanocomposite coatings of aluminum-carbon nanotubes (CNT) in the cold gas spraying process. Spray drying was used in order to obtain a good dispersion of carbon nanotubes in 
Al-Si microparticle eutectic powders. Spray-dried powders containing 5 wt.\% carbon nanotubes (CNTs) were mixed with pure aluminum powder to obtain total nominal carbon nanotube (CNT) compositions in the coating material of $0.5 \mathrm{wt} . \%$ and $1 \mathrm{wt} . \%$. As a result of cold spraying, coatings with a thickness of $500 \mu \mathrm{m}$ were obtained in which the carbon nanotubes were evenly distributed in the matrix. The carbon nanotubes were of shorter length as during the deposition process they fractured because of impact and shear between the Al-Si particles and the aluminum matrix. A. K. Keshri and the others [16] compared the impact on carbon nanotubes (CNTs) of various heat sources used during thermal spray processesplasma spraying (PS), high-velocity oxy fuel spraying (HVOF), cold spraying (CS) and plasma spraying of liquid precursor (PSLP) [40]. Carbon nanotubes (CNTs) have been successfully preserved as reinforcements in composite metal and ceramic coatings in all thermal spray processes, except for PSLP. There is no data in the literature regarding tribological properties of powder flame sprayed (PFS) aluminum and nickel coatings reinforced with carbon nanotubes (CNT). The purpose of this article is to present the state of knowledge in this area of research, and present the possibility of using powder flame spray technology (PFS) to produce composite coatings with a metallic matrix reinforced with carbon nanotubes (CNT).

\section{MATERIALS AND METHODS}

\section{Aim of study}

The conducted studies were aimed at comparing the structure, chemical composition, hardness, and resistance to abrasive and erosive wear of nickel and aluminum flame sprayed coatings reinforced with Nanocyl NC 7000 carbon nanotubes in amount of 0.5 wt.\%, 1 wt.\% with a reference coatings made of spherical pure nickel powder 2N5 Ni 99.5\% (US Research Nanomaterials Inc. Houston, TX USA) and aluminum powder EN AW 1000 series (Metallisation Ltd., West Midlands, UK) on non-alloy S235J0 steel. The scope of research included:

- preparation of material for spraying,

- selection process parameters for each of the coating

- coating manufacturing,

- examining the structure and tribological properties of nickel and aluminum coatings reinforced with carbon nanotubes,

- comparison of obtained samples with coatings made of nickel and aluminum powders without the addition of carbon nanotubes.

\section{Materials, devices, and spraying parameters}

The conducted studies were aimed at comparing the structure, chemical composition, hardness, and resistance to abrasive and erosive wear of nickel and aluminum flame sprayed coatings reinforced with Nanocyl The additional material for flame spraying was obtained by mixing appropriate proportions of nickel powder (table 1) and aluminum powder (table 2) with carbon nanotubes in the ball mill. Carbon nanotubes that were used in the test are the commercially available multi-walled carbon nanotubes MWCNTs, produced in the Catalytic Chemical Vapor Deposition (CCVD) process, NANOCYLTM NC7000 (Belgium Nanocyl SA, Sambreville, Belgium). 
Table 1. Specification of nickel powder 2N5 (Ni 99.5\%)

\begin{tabular}{cccc}
\hline Specification & Unit & Guaranteed parameters & Trace-element contents \\
\hline Nickel content $(\mathrm{Ni})$ & $\%$ & $\min 99.5$ & 99.6 \\
Iron content $(\mathrm{Fe})$ & $\%$ & $\max 0.02$ & 0.02 \\
Magnesium content $(\mathrm{Mg})$ & $\%$ & $\max 0.02$ & 0.02 \\
Lead content $(\mathrm{Pb})$ & $\%$ & $\max 0.002$ & 0.001 \\
Copper content $(\mathrm{Cu})$ & $\%$ & $\max 0.012$ & 0.015 \\
Calcium content $(\mathrm{Ca})$ & $\%$ & $\max 0.01$ & 0.01 \\
Cobalt $(\mathrm{Co})$ & $\%$ & $\max 0.003$ & 0.002 \\
Oxygen $(\mathrm{O})$ & $\%$ & $\max 0.05$ & 0.06 \\
Sulfur content $(\mathrm{S})$ & $\%$ & $\max 0.001$ & 0.001 \\
Others & $\%$ & $\max 0.5$ & 0.271 \\
Moisture & $\%$ & $\max 0.1$ & 0.08 \\
Bulk density & $\mathrm{g} / \mathrm{dm}$ & $\min 1900$ & 2150 \\
Granulation above $0.045 \mathrm{~mm}$ & $\%$ & $85.0-100.0$ & 96.0 \\
Granulation above $0.1 \mathrm{~mm}$ & $\%$ & $5.0-30.0$ & 12.1 \\
Granulation above $0.16 \mathrm{~mm}$ & $\%$ & $\max 5.0$ & 0.0 \\
\hline
\end{tabular}

Table 2. Specification of aluminum powder EN AW 1000 series

\begin{tabular}{cccc}
\hline Specification & Unit & Guaranteed parameters & Trace-element contents \\
\hline Aluminum content $(\mathrm{Al})$ & $\%$ & $\min 99.7$ & 99.7 \\
Iron content $(\mathrm{Fe})$ & $\%$ & $\max 0.2$ & 0.2 \\
Silicon content $(\mathrm{Si})$ & $\%$ & $\max 0.12$ & 0.12 \\
Copper content $(\mathrm{Cu})$ & $\%$ & $\max 0.004$ & 0.004 \\
Moisture & $\%$ & $\max 0.1$ & 0.1 \\
Bulk density & $\mathrm{g} / \mathrm{dm}^{3}$ & $\operatorname{min~} 1000$ & 1050 \\
Granulation above $0.045 \mathrm{~mm}$ & $\%$ & $85.0-100.0$ & 98.0 \\
Granulation above $0.1 \mathrm{~mm}$ & $\%$ & $5.0-30.0$ & 15.3 \\
Granulation above $0.16 \mathrm{~mm}$ & $\%$ & $\max 5.0$ & 0.0 \\
\hline
\end{tabular}

The subsonic flame spraying process was carried out cold in accordance with the standard EN 13507:2018 on workstation, equipped with hand-guided modern oxyacetylene system CastoDyn DS 8000 (Eutectic Castolin, Gliwice, Poland). The final surface preparation was done by shot blasting sheets prior to spraying with sharp-edged cast iron of $0.5-1.5 \mathrm{~mm}$ shot grain size in accordance with standard ISO 2063-1:2017. The final surface roughness of the steel substrate after shot blasting was $\mathrm{R}_{\mathrm{a}}=12 \mu \mathrm{m}, \mathrm{R}_{\mathrm{z}}=85 \mu \mathrm{m}$. Before the spraying process, steel plates with dimensions of $150 \times 150 \times 5 \mathrm{~mm}$ were preheated with a gas burner up to a temperature of $40^{\circ} \mathrm{C}$ (the temperature of preheating was measured using pyrometer). The standard spray modules SSM are optimized to spray different materials. The nozzles regulating the outlet of the spray flame SSM 10 and SSM 40 were used for nickel and aluminum coatings, respectively. The acetylene valve was adjusted for a neutral flame (ratio $\mathrm{O}_{2} / \mathrm{C}_{2} \mathrm{H}_{2}=1.2$ ). This allowed to obtain the proper spray jet [26,34]. The flame jet burner was guided in a horizontal position covering the whole surface of the sheet. During the process, the spraying direction was changed several times by $90^{\circ}$, until the obtained thickness of coating was about $1.0 \mathrm{~mm}$. The distance between the torch and the sprayed surface was 200 $\mathrm{mm}$. The parameters and the flame types were constant for each test (Fig. 1). The criterion for visual assessment of the powder coatings quality was to obtain the surface layers characterized by the appropriate thickness, good adhesion to the substrate, low porosity, continuity, and uniformity of the obtained coatings. The optimal flame spraying parameters of nickel and aluminum coatings reinforced with carbon nanotubes were determined on the basis of preliminary technological tests (table 3 ). 
a)

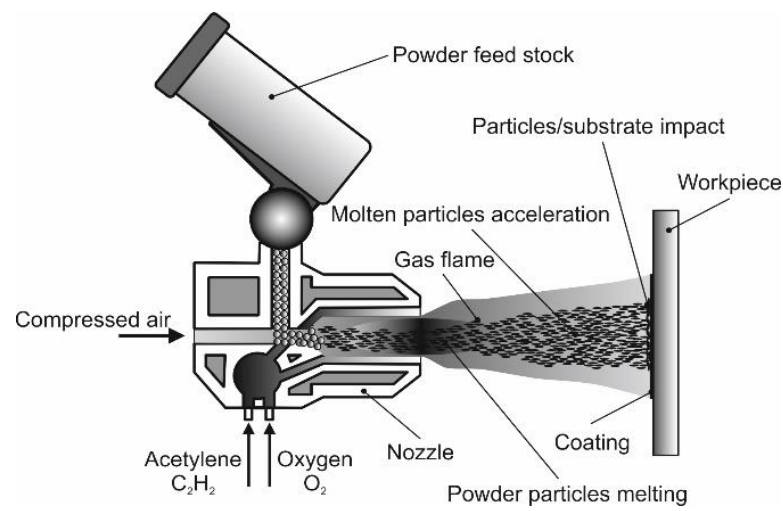

b)

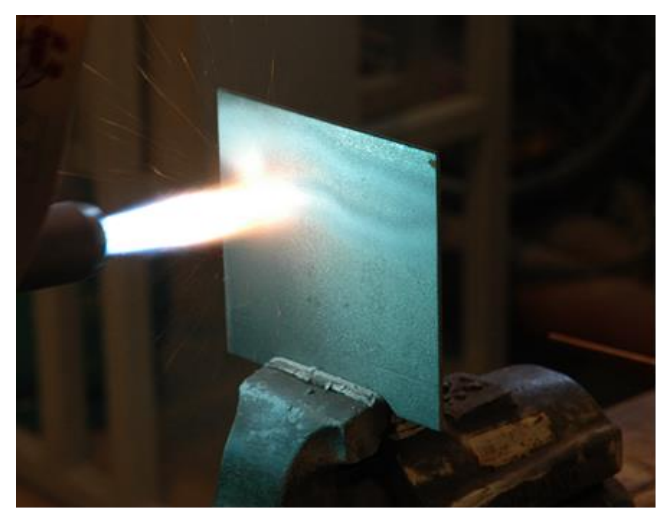

Fig. 1 Flame spraying process: a) a diagram of handheld flame jet burner, b) a photo from trials of flame spraying aluminum coatings with CastoDyn DS 8000 burner

Table 3. Parameters of flame sprayed nickel and aluminum coatings reinforced with carbon nanotubes

\begin{tabular}{|c|c|c|c|c|c|c|c|c|}
\hline $\begin{array}{l}\text { Sample } \\
\text { number }\end{array}$ & $\begin{array}{l}\text { Type of } \\
\text { powder }\end{array}$ & $\begin{array}{l}\text { Standard } \\
\text { spray } \\
\text { module }\end{array}$ & $\begin{array}{c}\text { Oxygen } \\
\text { pressure } \\
{[\mathrm{MPa}]}\end{array}$ & $\begin{array}{c}\text { Acetylene } \\
\text { pressure } \\
{[\mathrm{MPa}]}\end{array}$ & $\begin{array}{c}\text { Assisted gas } \\
\text { (compressed } \\
\text { air) pressure } \\
{[\mathrm{MPa}]}\end{array}$ & $\begin{array}{l}\text { Number } \\
\text { of the } \\
\text { orifice } \\
\text { for the } \\
\text { powder }\end{array}$ & $\begin{array}{c}\text { Mass of } \\
\text { used } \\
\text { powder } \\
{[\mathrm{g}]}\end{array}$ & $\begin{array}{c}\text { Powder } \\
\text { yield } \\
{[\%]}\end{array}$ \\
\hline 1 & $\mathrm{Ni}$ & & 0.3 & 0.07 & 0.1 & 1 & 186.7 & 69.5 \\
\hline 2 & $\mathrm{Ni}+0.5 \% \mathrm{CNT}$ & SSM 10 & 0.3 & 0.07 & 0.1 & 1 & 190.1 & 71.4 \\
\hline 3 & $\mathrm{Ni}+1 \% \mathrm{CNT}$ & & 0.3 & 0.07 & 0.1 & 1 & 188,1 & 70.4 \\
\hline 4 & $\mathrm{Al}$ & & 0.4 & 0.07 & 0.3 & 2 & 93.5 & 60.3 \\
\hline 5 & $\begin{array}{c}\mathrm{Al}+0.5 \% \\
\mathrm{CNT}^{1)}\end{array}$ & SSM 40 & 0.4 & 0.07 & 0.3 & 2 & 97.0 & 56.2 \\
\hline 6 & $\mathrm{Al}+1 \% \mathrm{CNT}$ & & 0.4 & 0.07 & 0.3 & 2 & 100.8 & 57.0 \\
\hline
\end{tabular}

\section{Visual and metallographic examination}

In each case, the entire surface of the sample was subjected to visual tests to assess the quality and identify any imperfections in the form of cracks, discontinuities, unevenness, porosity or lack of coating adhesion. Macro and microscopic examinations were performed on the Olypmus GX 71 optical microscope (Olympus Corporation, Tokyo, Japan). The observations were made on the cross-section of metallographic samples cut from the centre of element. The samples were polished and etched in Aqua Regia. Selected areas of flame sprayed coatings have been subjected to chemical composition analysis on JEOL 5800LV SEM scanning microscope and also EDX (Jeol Ltd., Tokyo, Japan).

\section{Raman analysis of carbon nanotubes}

Raman microscopy was chosen to unambiguously confirm the presence of carbon nanotubes in a coating. Raman spectroscopy is one of the common spectral analysis methods used to obtain the structure and vibration information of CNTs. The Raman spectra of the nickel coatings with the addition of carbon nanotubes, and also aluminum coatings with the addition of carbon nanotubes were obtained using WITec Alfa 300R Raman spectrometer equipped with a confocal microscope, a 532-nm Nd:YAG diode laser and a highly sensitive back-illuminated Newton-CCD camera. The data were collected at room temperature with a $50 \times$ objective $(\mathrm{NA}=0.5)$, accumulated with $10 \mathrm{~s}$ exposure time and 100 repetitions in the spectral range between 200 and $3500 \mathrm{~cm}^{-1}$. For each sample, the Raman scattering was 
measured at different places to make sure that the probed materials are homogeneous, and the collected spectra provide the representative structural information of the coating material. The fitting procedure of Raman bands was performed with the Fityk software.

\section{Hardness measurements of coatings}

The coating-hardness measurement was made with the Vickers method using Microhardness Tester 401 MVD ${ }^{\mathrm{TM}}$ (Wilson Instruments An Instron Company, Norwood, MA, USA). The examinations were carried out in conformity to ISO 6507-1:2018 standard. The load applied during the hardness measurement was $4.903 \mathrm{~N}$ (HV 0.5) for nickel coatings and $0.9807 \mathrm{~N}$ (HV 0.1) for aluminum coatings. The hardness measurement was made at the polished cross-section of the samples with flame sprayed coatings. Ten hardness measuring points were made on the cross-section each sprayed coating.

\section{Erosive wear resistance of coatings}

The erosive wear tests of flame sprayed coatings were carried out in accordance with ASTM G76-18, as shown in Fig. 2. Aluminum oxide powder $\left(\mathrm{Al}_{2} \mathrm{O}_{3}\right)$ with particle diameter of $71 \mu \mathrm{m}$ was used as the erodent material. Particle velocity was set at $70 \pm 2 \mathrm{~m} / \mathrm{s}$, the erodent expenditure was $2.0 \pm 0.5 \mathrm{~g} / \mathrm{min}$ and the nozzle distance from the sample surface was $10 \mathrm{~mm}$. The tests were carried out at $90^{\circ}$ and $30^{\circ}$ erodent impact angle. The average weight loss was determined on the basis of three tests. The erosion rate was determined according to the Equation (1):

$$
\text { erosion rate }\left[\frac{\mathrm{g}}{\mathrm{min}}\right]=\frac{\text { mass loss of sample }[\mathrm{g}]}{\text { exposure time }[\mathrm{min}]}
$$

However, the erosive wear resistance using Equation (2):

erosive wear resistance $\left[\frac{0.001 \mathrm{~mm}^{3}}{\mathrm{~g}}\right]=\frac{\text { volume loss of the sample }\left[\mathrm{mm}^{3}\right]}{\text { total mass of the erodent used in the test }[\mathrm{g}]}$

a)

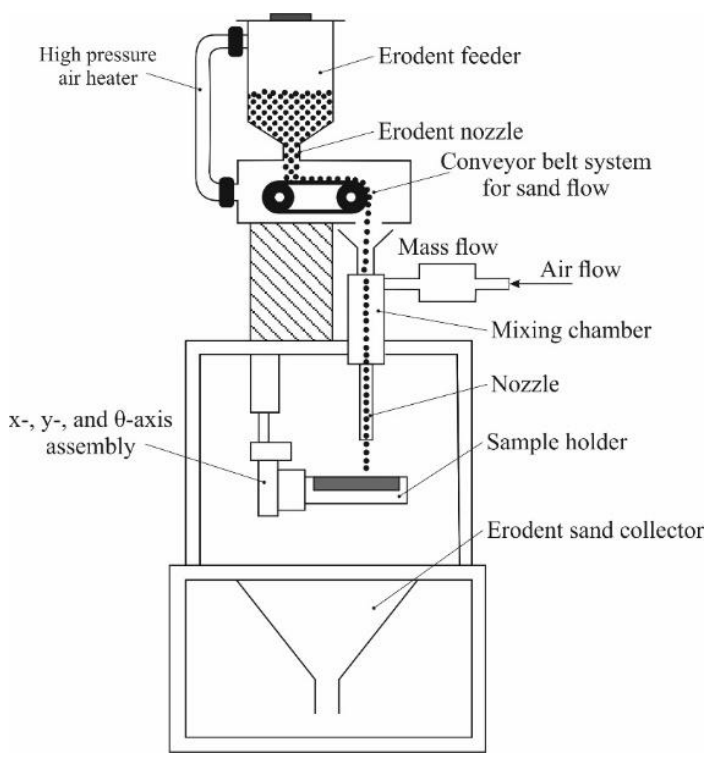

b)

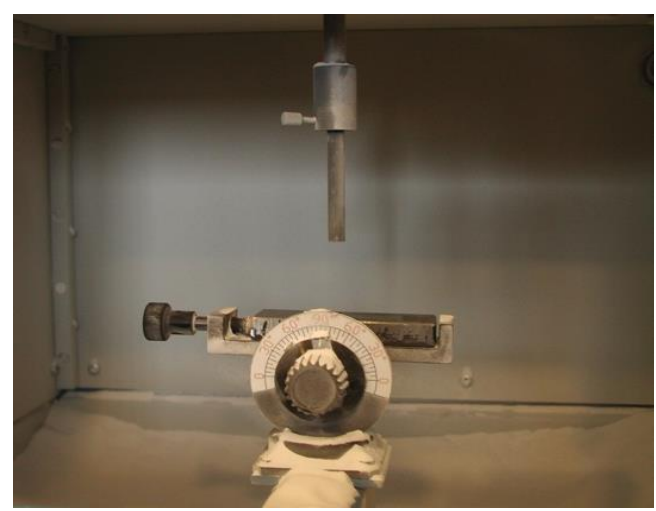

Fig. 2. Erosion resistance testing according to ASTM G 76-95: a) a schematic view, b) the interior view of the erosion measuring chamber 


\section{Abrasive wear resistance of coatings}

Metal-mineral wear resistance tests of nickel and aluminum matrix coatings were provided in accordance with ASTM G65-16, Procedure E [41]. During the test, the rubber-wheel made 1000 revolutions and the abrasive flow rate of A.F.S. Testing Sand 50-70 was $335 \mathrm{~g} / \mathrm{min}$. The force applied for pressing the test coupon against the wheel was TL $=130 \mathrm{~N}$ (test load-TL). After the abrasive wear resistance test, the test specimen was weighed at weight sensitivity $0,0001 \mathrm{~g}$. Converting mass loss to volume loss was as follows:

$$
\text { volume loss }\left[\mathrm{mm}^{3}\right]=\frac{\text { mass loss }[\mathrm{g}]}{\text { density }\left[\frac{\mathrm{g}}{\mathrm{cm}^{3}}\right]} \cdot 1000
$$

The tests were carried out on abrasion tester shown in Fig. 3.

a)

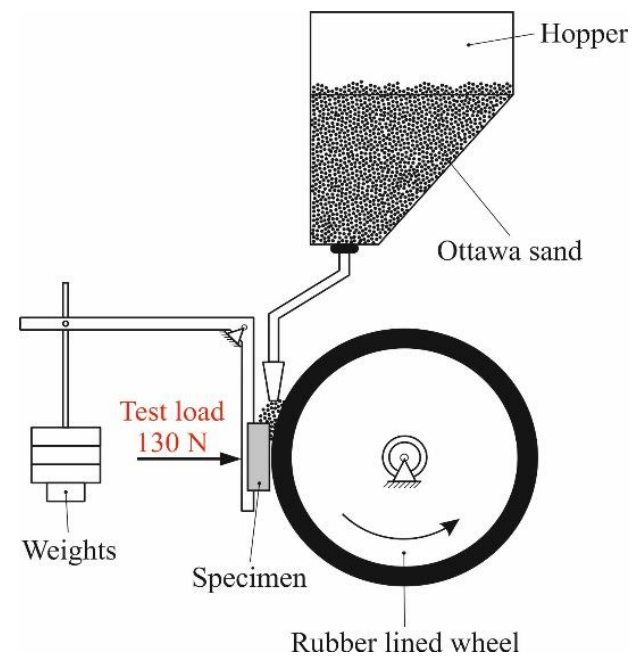

b)

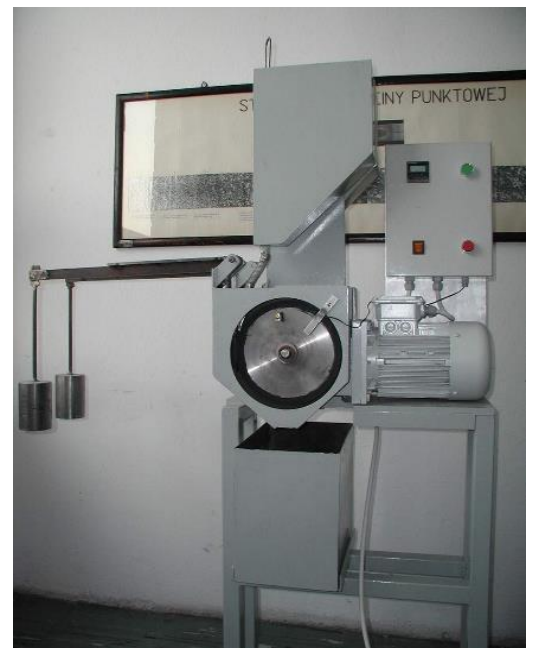

Fig. 3. Metal-mineral wear resistance test stand - according to ASTM G65-00, Procedure E standard: a) a schematic view, b) picture of the device used

\section{RESULTS}

\section{Metallographic test results}

The structure of each tested flame sprayed coating cross-section is presented in Fig. 4. The SEM structures of tested aluminum and nickel matrix coatings with chemical composition are presented in Fig. 5-10. 

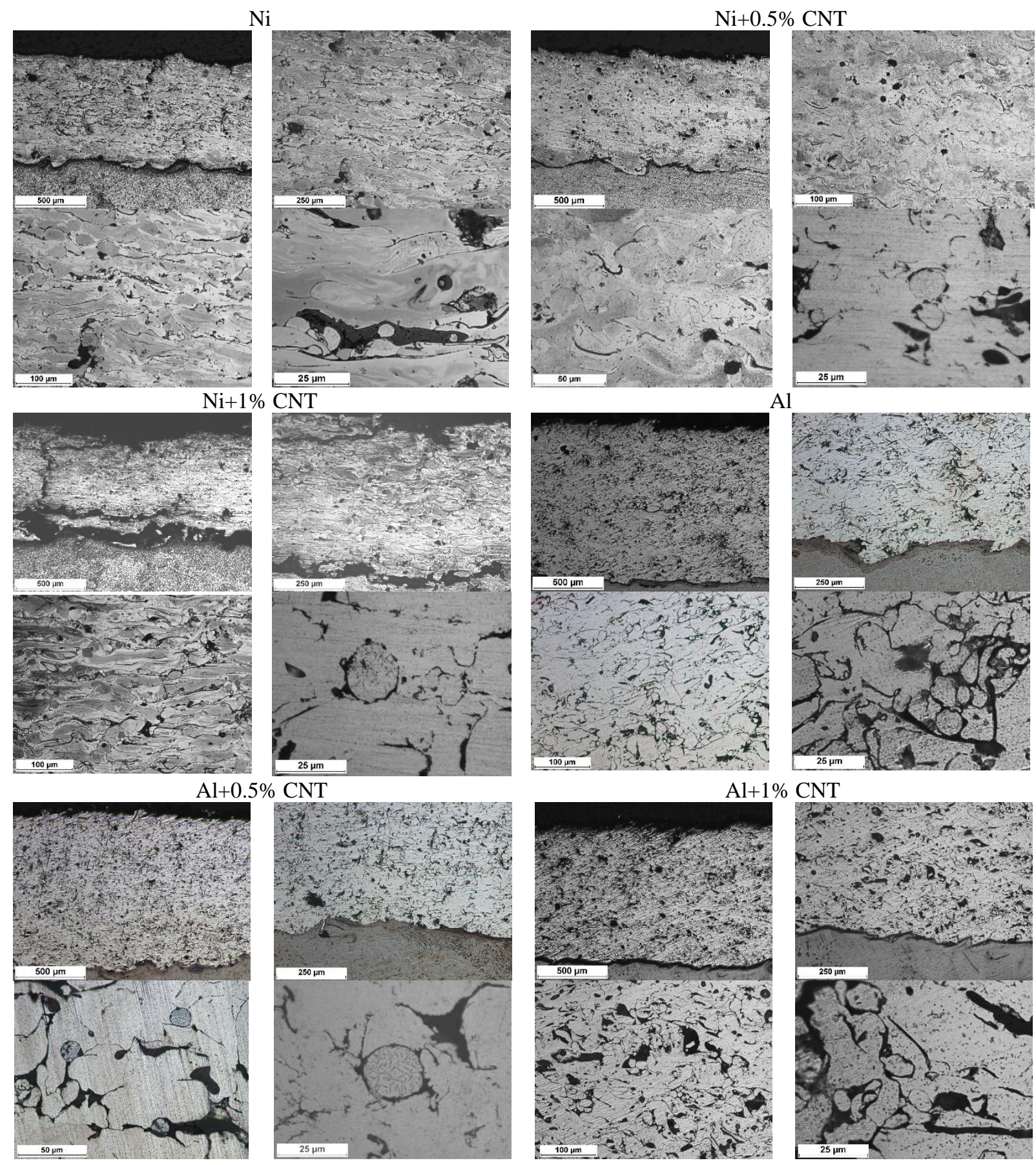

Fig. 4. The macro and microstructure of the flame sprayed pure aluminum and also aluminum matrix and nickel matrix with carbon nanotubes reinforcement coatings, etching: $\mathrm{HCl}_{+} \mathrm{HNO}_{3}$ 


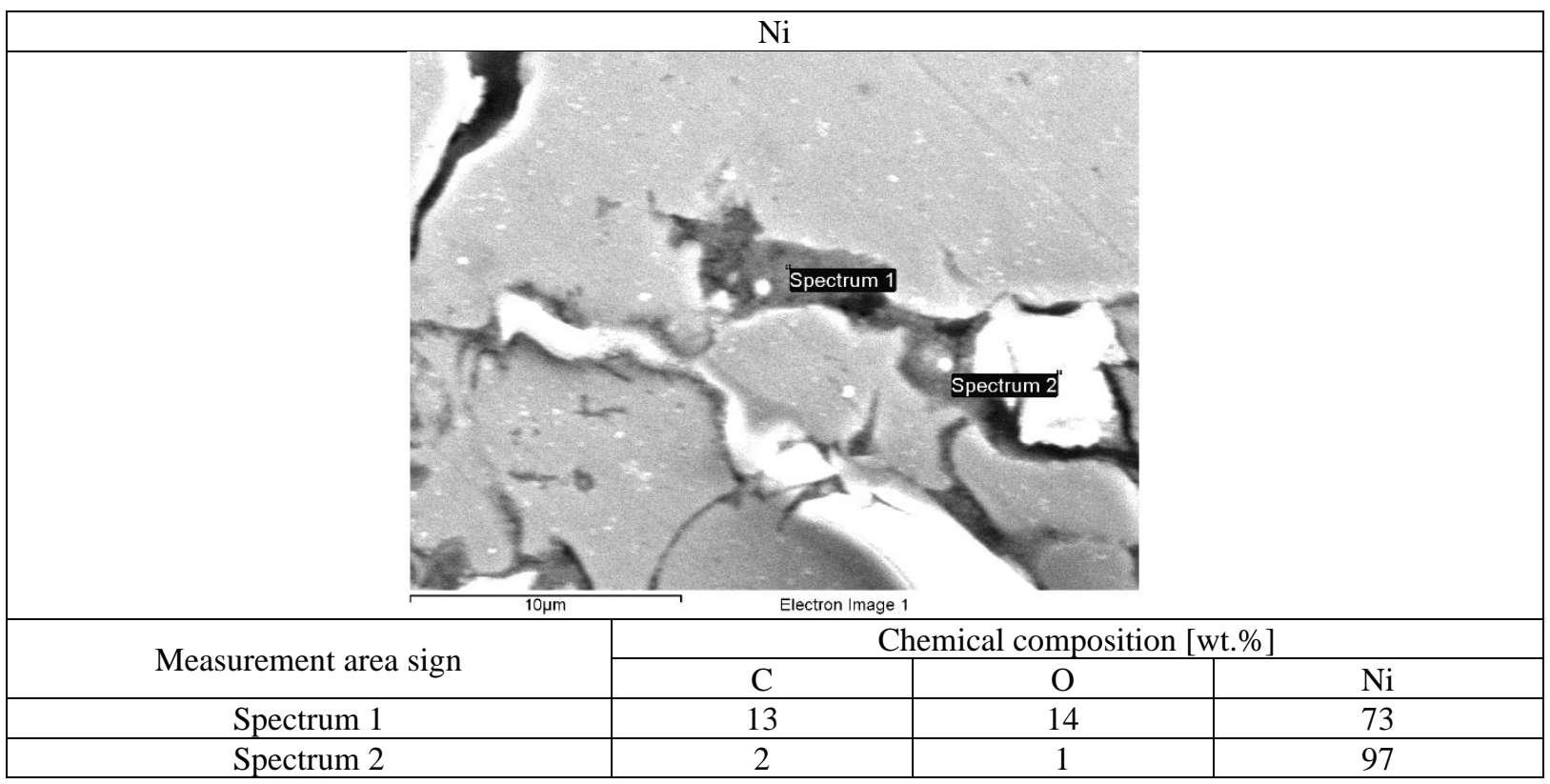

Fig. 5. The structure of $2 \mathrm{~N} 5$ (Ni 99.5\%) nickel powder flame sprayed coating with marked chemical composition tested areas on SEM

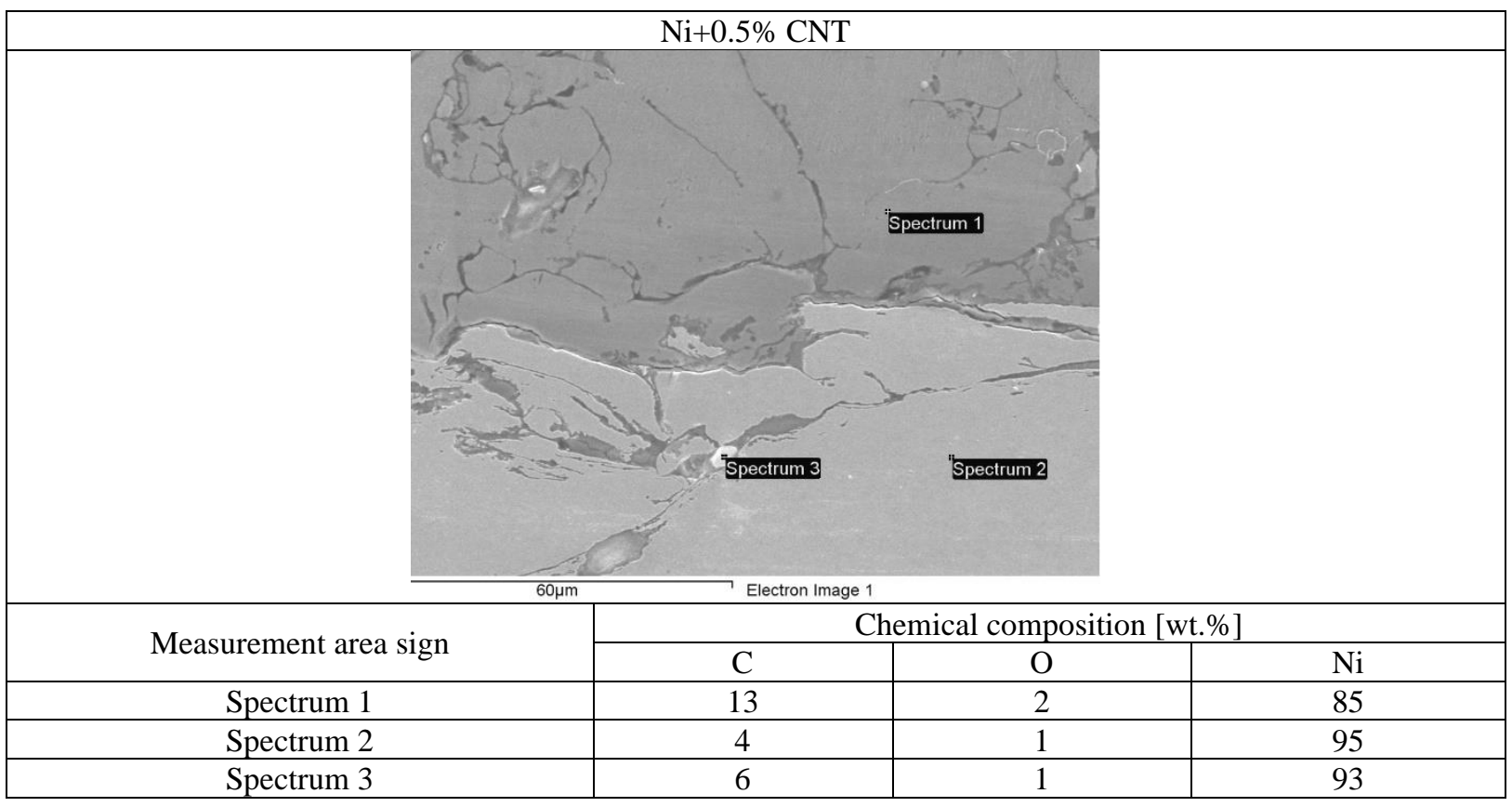

Fig. 6. The structure of nickel powder with $0.5 \mathrm{wt} . \%$ Nanocyl NC 7000 carbon nanotubes flame sprayed coating with marked chemical composition tested areas on SEM 


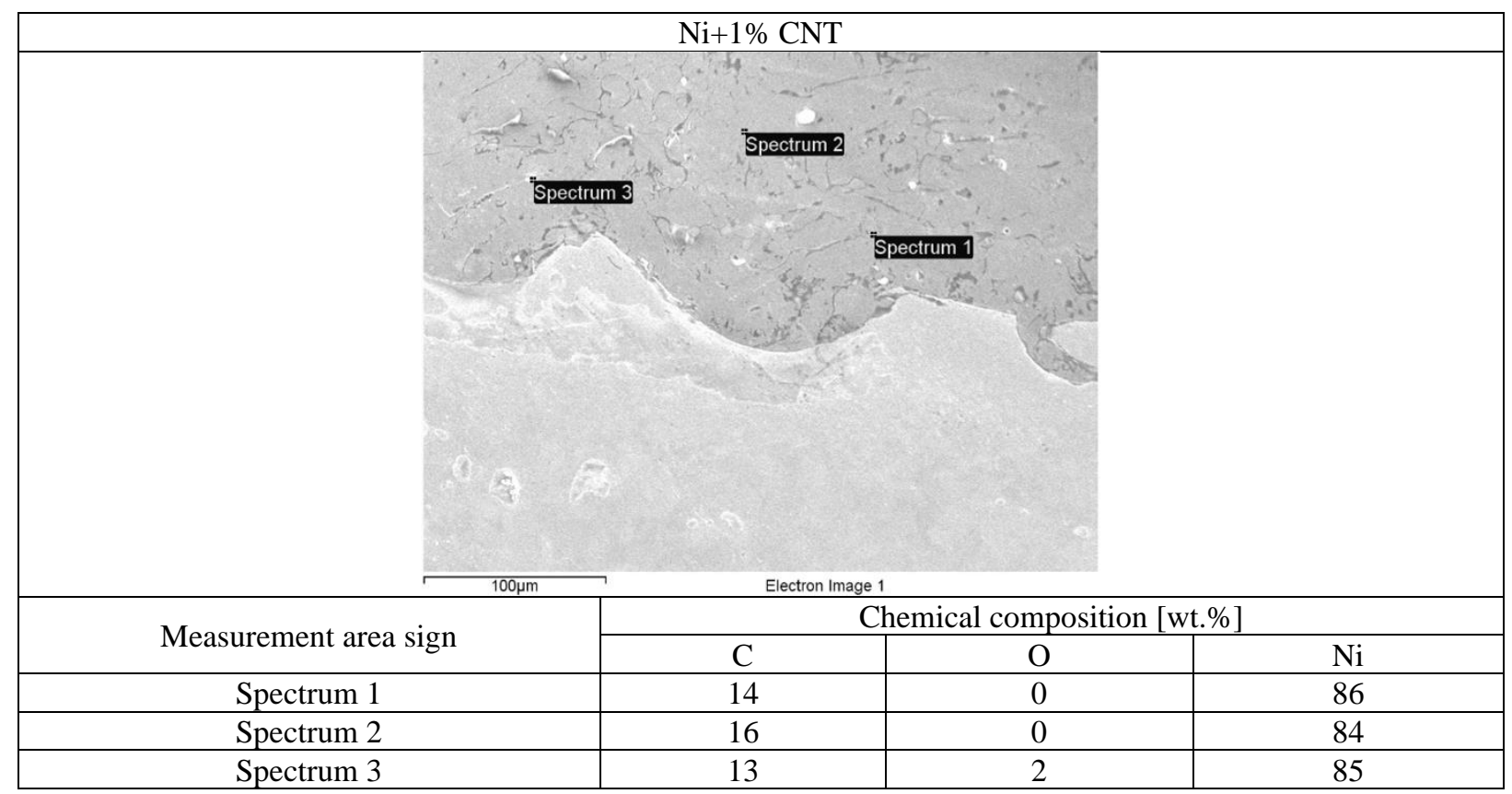

Fig. 7. The structure of nickel powder with 1 wt.\% Nanocyl NC 7000 carbon nanotubes flame sprayed coating with marked chemical composition tested areas on SEM

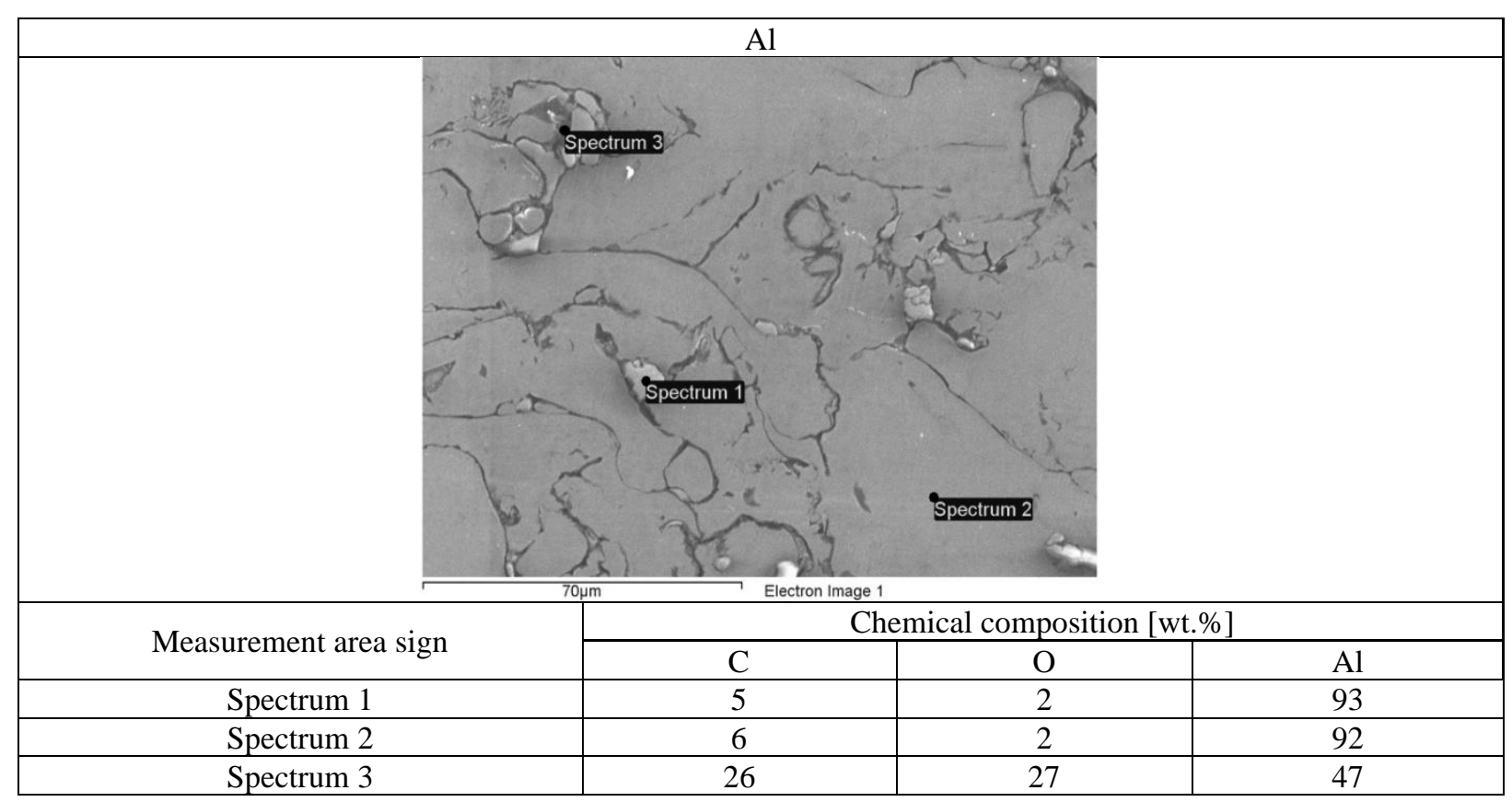

Fig. 8. The structure of EN AW 1000 aluminum powder flame sprayed coating with marked chemical composition tested areas on SEM 


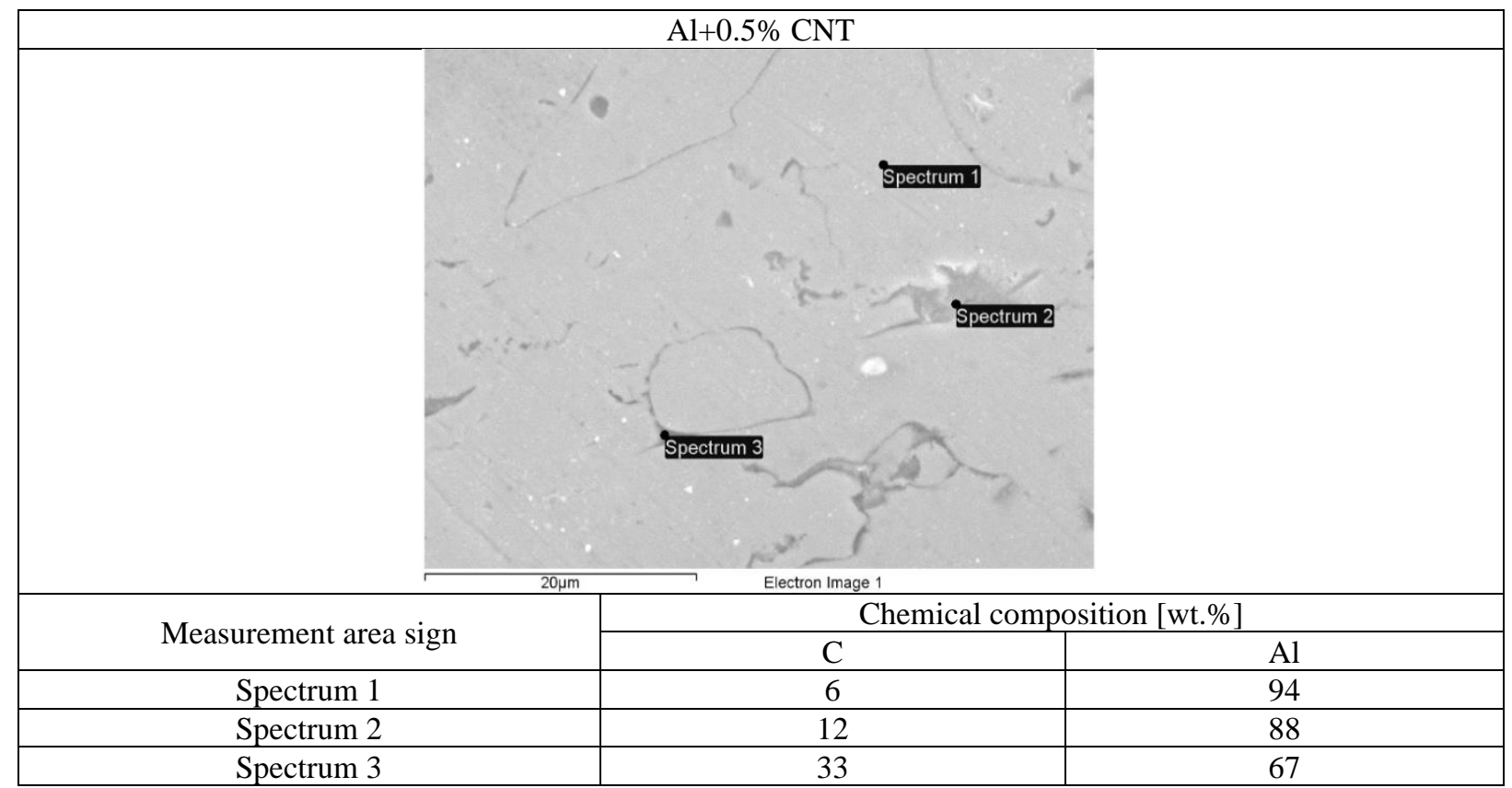

Fig. 9. The structure of aluminum powder with 0.5 wt.\% Nanocyl NC 7000 carbon nanotubes flame sprayed coating with marked chemical composition tested areas on SEM

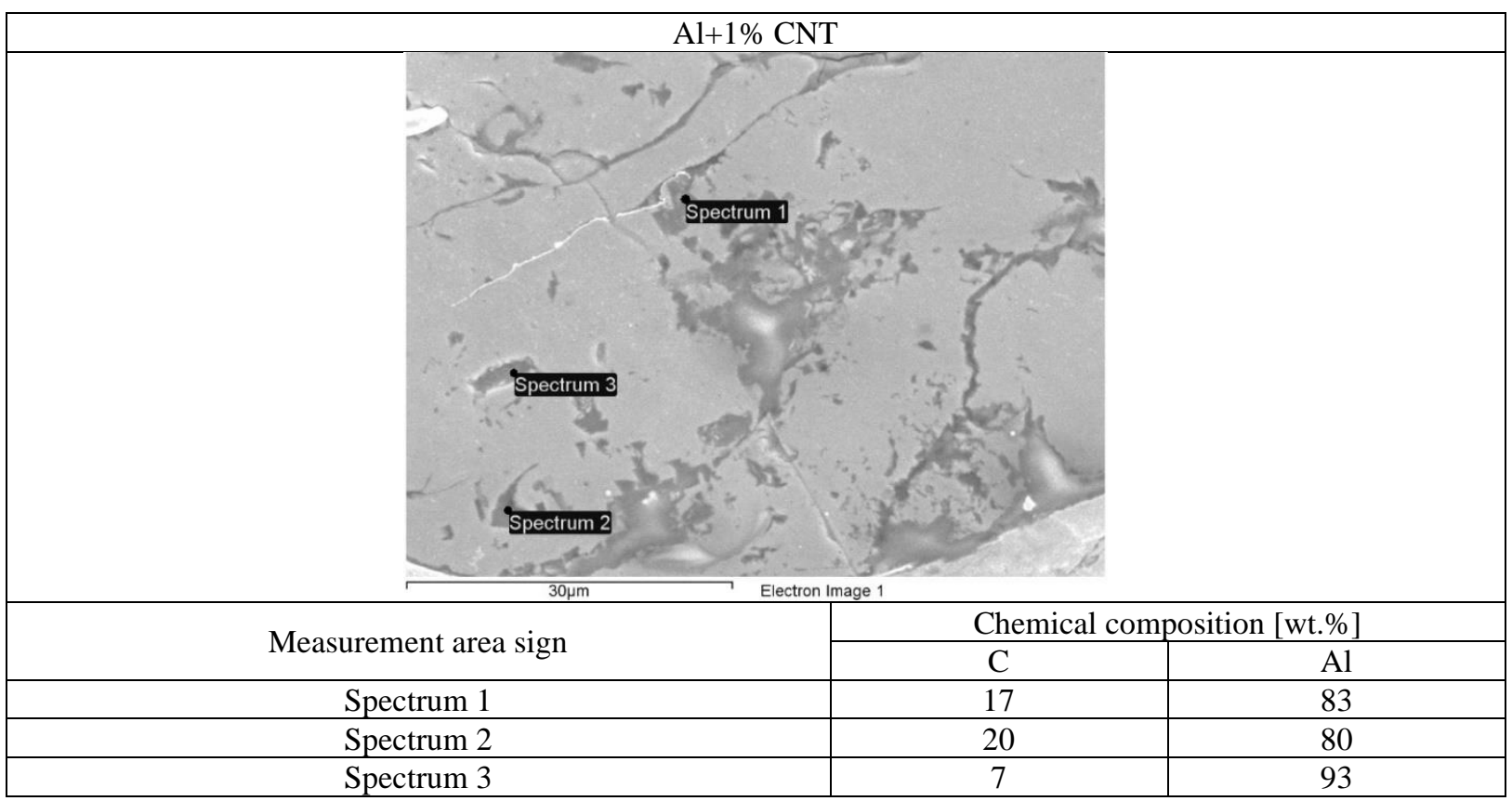

Fig. 10. The structure of aluminum powder with 1 wt.\% Nanocyl NC 7000 carbon nanotubes flame sprayed coating with marked chemical composition tested areas on SEM

\section{Raman spectroscopy results}

Raman test the responses to excitation with laser revealed very rich spectra, differing in the intensity of the indication for each sample. Figure 11 presents two examples, one for nickel coating with the addition of $0.5 \mathrm{wt} . \% \mathrm{CNT}$ and the other for aluminum coating with the addition of $1 \mathrm{wt} . \% \mathrm{CNT}$. 
a)

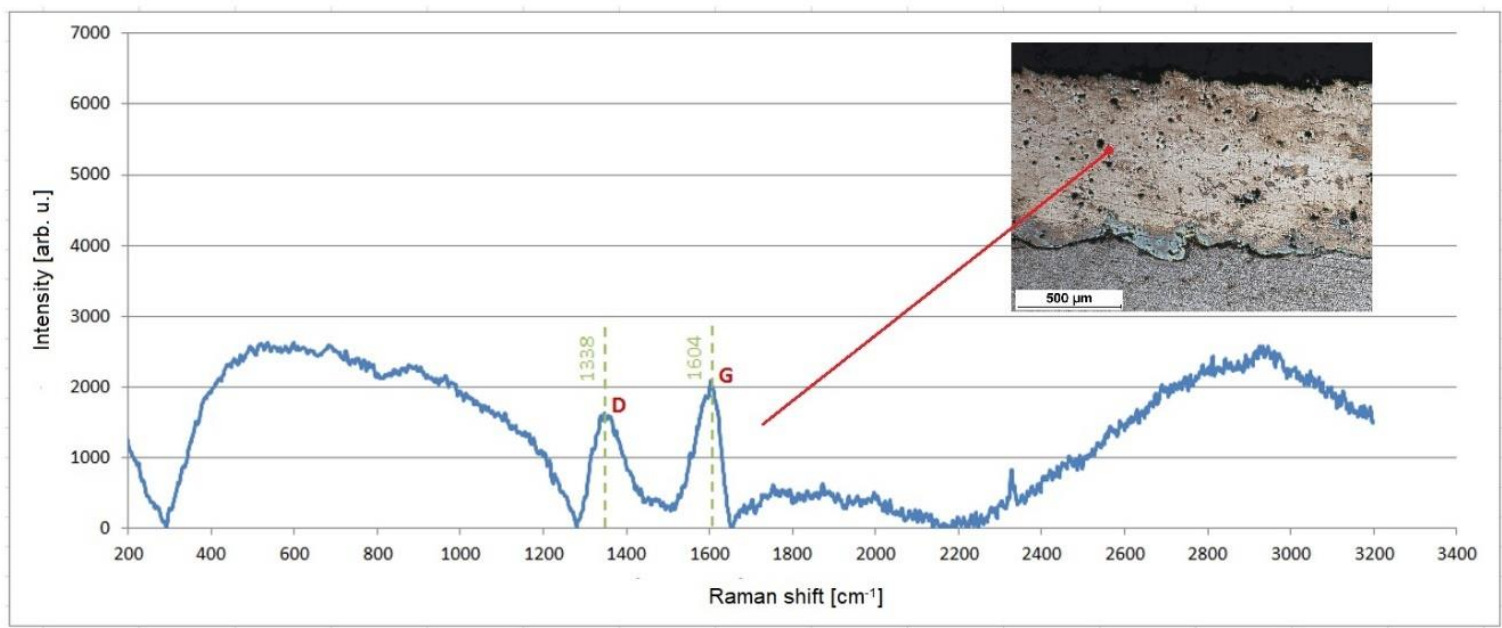

b)

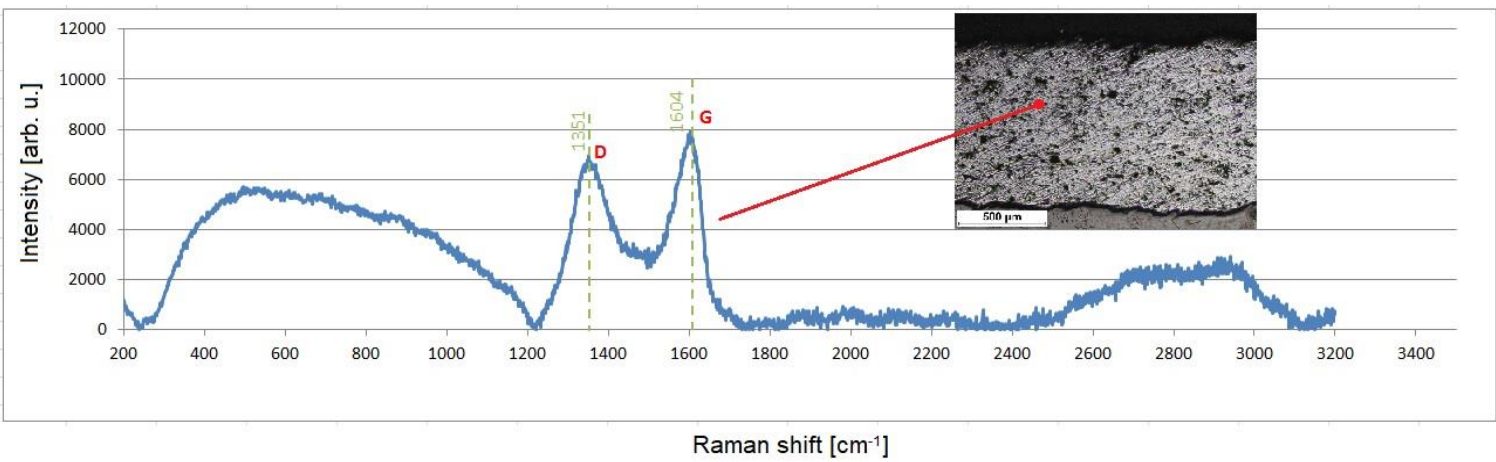

Fig. 11. Examples of the Raman spectra with marked peaks of carbon nanotubes for samples:

a) $\mathrm{Ni}+0.5 \% \mathrm{CNT}-1338$ and $1604 \mathrm{~cm}-1$, b) Al+1\% CNT - 1351 and $1609 \mathrm{~cm}-1$

\section{Hardness measurements}

The hardness measurements of the flame sprayed coatings using pure metal powders and powders with the addition of carbon nanotubes, were carried out on the surface at 5 points along one measuring line (table 4) and on cross-section of the samples (Fig. 12).

Table 4. Surface hardness results of the flame sprayed coatings using pure metal powders and powders reinforced with the addition of carbon nanotubes

\begin{tabular}{cccccccc}
\hline \multirow{2}{*}{ Specimen designation } & \multicolumn{7}{c}{ Measuring point } \\
\cline { 2 - 7 } & 1 & 2 & 3 & 4 & 5 & Average & Standard deviation \\
\hline Ni & 522.6 & 512.9 & 581.4 & 565.0 & 534.1 & 543.2 & 29.0 \\
$\mathrm{Ni}+0.5 \% \mathrm{CNT}$ & 575.2 & 562.0 & 601.7 & 521.5 & 551.2 & 562.3 & 29.6 \\
$\mathrm{Ni}+1 \% \mathrm{CNT}$ & 617.5 & 587.4 & 559.8 & 658.7 & 608.2 & 606.3 & 36.7 \\
\hline $\mathrm{7}$ & 35.2 & 32.5 & 34.8 & 37.2 & 35.1 & 34.96 & 1.67 \\
$\mathrm{Al}+0.5 \% \mathrm{CNT}$ & 59.2 & 62.8 & 56.5 & 54.2 & 55.5 & 57.64 & 3.42 \\
$\mathrm{Al}+1 \% \mathrm{CNT}$ & 41.2 & 43.2 & 37.5 & 39.2 & 38.7 & 39.96 & 2.25 \\
\hline
\end{tabular}




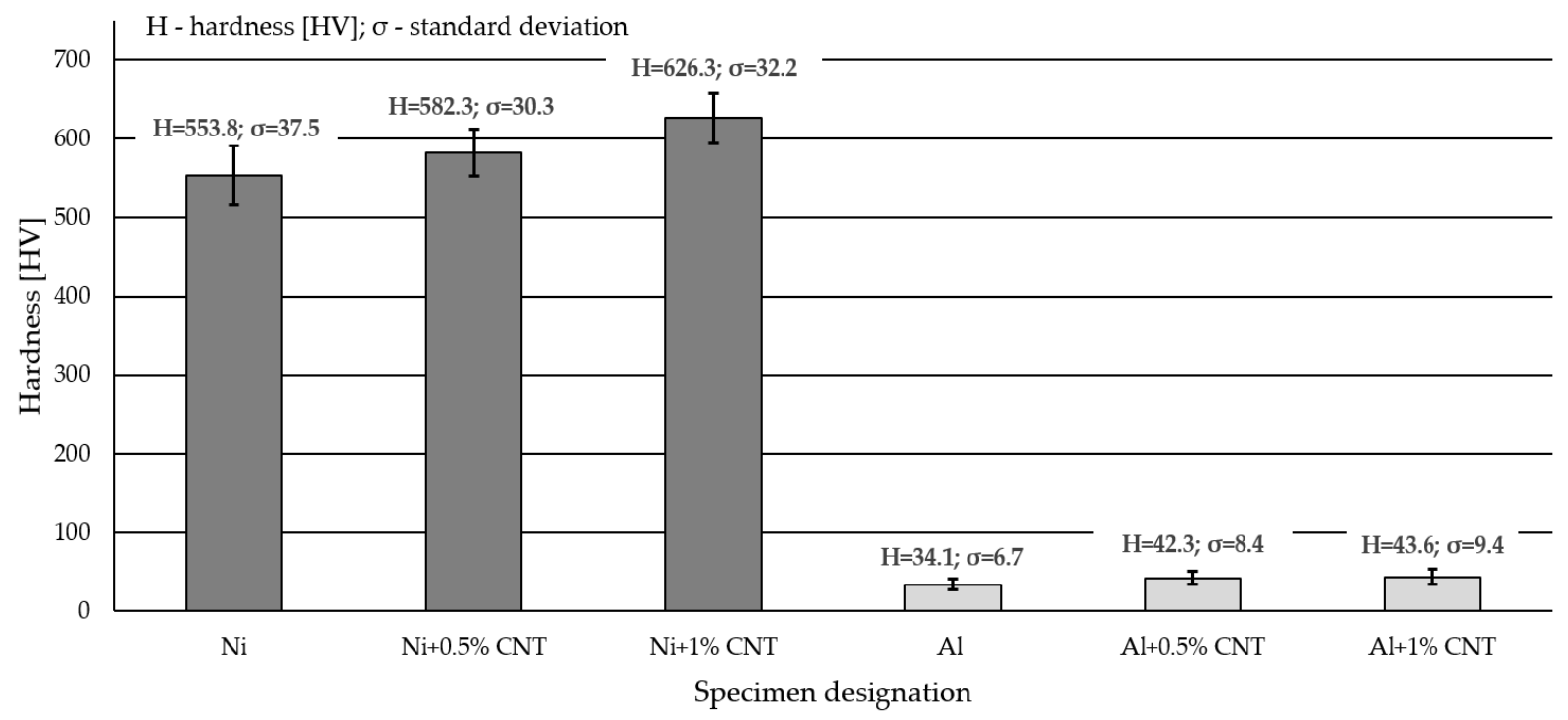

Fig. 12. Comparison of average cross-sectional hardness and standard deviation for each of the investigated coatings

\section{Tests results of the coatings erosive wear resistance}

The relative erosive wear resistance test results of the flame sprayed aluminum, aluminum with carbon nanotube reinforcement and aluminum with filter dust carburite reinforcement coatings are presented in table 5 and Fig. 13.

Table 5. Summary of results obtained during the erosion wear test ASTM G76-95

\begin{tabular}{|c|c|c|c|c|c|}
\hline $\begin{array}{c}\text { Erodent strike angle } \\
{\left[{ }^{\circ}\right]}\end{array}$ & $\begin{array}{c}\text { Specimen } \\
\text { designation }\end{array}$ & $\begin{array}{c}\text { Mass loss } \\
{[\mathrm{g}]}\end{array}$ & $\begin{array}{l}\text { Volume } \\
\text { loss } \\
{\left[\mathrm{mm}^{3}\right]}\end{array}$ & $\begin{array}{c}\text { Erosion rate } \\
{[\mathrm{g} / \mathrm{min}]}\end{array}$ & $\begin{array}{c}\text { Resistance to erosion as per } \\
\text { ASTM G76 } \\
{\left[0.001 \mathrm{~mm}^{3} / \mathrm{g}\right]}\end{array}$ \\
\hline \multirow{3}{*}{90} & $\mathrm{Ni}$ & 0.0046 & 0.517 & 0.06461 & 0.03190 \\
\hline & $\mathrm{Ni}+0.5 \% \mathrm{CNT}$ & 0.0049 & 0.551 & 0.06882 & 0.03399 \\
\hline & $\mathrm{Ni}+1 \% \mathrm{CNT}$ & 0.0051 & 0.573 & 0.07163 & 0.03537 \\
\hline \multirow{3}{*}{30} & $\mathrm{Ni}$ & 0.0044 & 0.494 & 0.06180 & 0.03052 \\
\hline & $\mathrm{Ni}+0.5 \% \mathrm{CNT}$ & 0.0040 & 0.449 & 0.05618 & 0.02774 \\
\hline & $\mathrm{Ni}+1 \% \mathrm{CNT}$ & 0.0038 & 0.427 & 0.05337 & 0.02636 \\
\hline \multirow{3}{*}{90} & $\mathrm{Al}$ & 0.0054 & 1.985 & 0.00068 & 0.12255 \\
\hline & $\mathrm{Al}+0.5 \% \mathrm{CNT}$ & 0.0117 & 4.301 & 0.00146 & 0.26552 \\
\hline & $\mathrm{Al}+1 \% \mathrm{CNT}$ & 0.0071 & 2.610 & 0.00089 & 0.16113 \\
\hline \multirow{3}{*}{30} & $\mathrm{Al}$ & 0.0036 & 1.324 & 0.00045 & 0.08170 \\
\hline & $\mathrm{Al}+0.5 \% \mathrm{CNT}$ & 0.0066 & 2.426 & 0.00083 & 0.14978 \\
\hline & $\mathrm{Al}+1 \% \mathrm{CNT}$ & 0.0045 & 1.654 & 0.00056 & 0.10212 \\
\hline
\end{tabular}

Notes: density of nickel spray coating $8.90\left[\mathrm{~g} / \mathrm{cm}^{3}\right]$, density of aluminum spray coating $2.72\left[\mathrm{~g} / \mathrm{cm}^{3}\right]$, mass of erodent used $16.2[\mathrm{~g}]$, test time $8[\mathrm{~min}]$ 


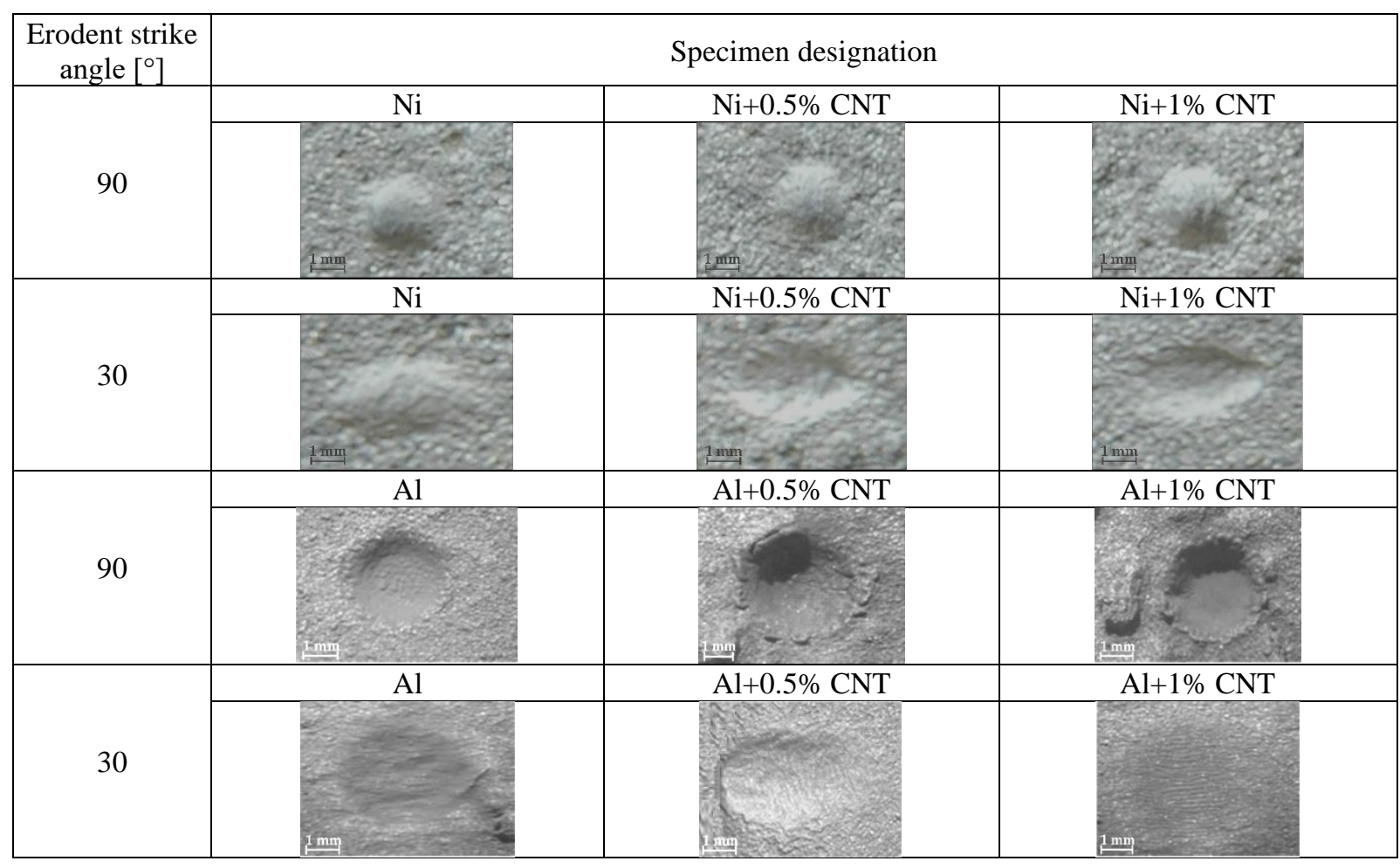

Fig. 13. The surfaces of flame sprayed aluminum and aluminum matrix reinforced with carbon material coatings after erosive wear resistance tests, comparison the erosion effect on samples surfaces for each tested angle of erodent particles incidence

\section{Tests results of the coatings wear resistance}

The wear resistance test results of the flame sprayed aluminum, aluminum with carbon nanotube reinforcement and aluminum with filter dust carburite reinforcement coatings are presented in table 6 and Fig. 15. The metal-mineral type wear resistance of the flame sprayed aluminum with carbon nanotubes and aluminum with carburite coatings were compared to the flame sprayed pure aluminum coating.

Table 6. Summary of results obtained during the abrasive wear test ASTM G65

\begin{tabular}{|c|c|c|c|c|c|c|c|}
\hline $\begin{array}{c}\text { Specimen } \\
\text { designation }\end{array}$ & $\begin{array}{l}\text { Number of } \\
\text { specimen }\end{array}$ & $\begin{array}{c}\text { Weight } \\
\text { before test } \\
{[\mathrm{g}]}\end{array}$ & $\begin{array}{l}\text { Weight } \\
\text { after test } \\
{[\mathrm{g}]}\end{array}$ & $\begin{array}{c}\text { Mass loss } \\
{[\mathrm{g}]}\end{array}$ & $\begin{array}{c}\text { Average } \\
\text { mass loss } \\
{[\mathrm{g}]}\end{array}$ & $\begin{array}{c}\text { Average } \\
\text { volume loss } \\
{\left[\mathrm{mm}^{3}\right]}\end{array}$ & $\begin{array}{l}\text { Relative }^{1)} \\
\text { abrasion } \\
\text { resistance }\end{array}$ \\
\hline \multirow{2}{*}{$\mathrm{Ni}$} & N1-1 & 55.9957 & 55.7516 & 0,2441 & \multirow{2}{*}{0.2507} & \multirow{2}{*}{28.1685} & \multirow{2}{*}{1.00} \\
\hline & N1-2 & 56.0531 & 55.7958 & 0,2573 & & & \\
\hline \multirow{2}{*}{$\mathrm{Ni}+0.5 \% \mathrm{CNT}$} & N2-1 & 56.0118 & 55.7824 & 0,2294 & \multirow{2}{*}{0.2245} & \multirow{2}{*}{25.2247} & \multirow{2}{*}{1.12} \\
\hline & N2-2 & 57.0224 & 56.8028 & 0,2196 & & & \\
\hline \multirow{2}{*}{$\mathrm{Ni}+1 \% \mathrm{CNT}$} & N3-1 & 58.3133 & 58.1147 & 0,1986 & \multirow{2}{*}{0.2000} & \multirow{2}{*}{22.4719} & \multirow{2}{*}{1.25} \\
\hline & N3-2 & 57.7197 & 57.5183 & 0,2014 & & & \\
\hline \multirow{2}{*}{$\mathrm{Al}$} & A1-1 & 43.9675 & 43.8413 & 0.1262 & \multirow{2}{*}{0.1418} & \multirow{2}{*}{52.1324} & \multirow{2}{*}{1.00} \\
\hline & A1-2 & 42.3855 & 42.2281 & 0.1574 & & & \\
\hline \multirow{2}{*}{$\mathrm{Al}+0.5 \% \mathrm{CNT}$} & A2-1 & 56.5170 & 56.3924 & 0.1246 & \multirow{2}{*}{0.1286} & \multirow{2}{*}{47.2610} & \multirow{2}{*}{1.10} \\
\hline & A2-2 & 53.8604 & 53.7279 & 0.1325 & & & \\
\hline \multirow{2}{*}{$\mathrm{Al}+1 \% \mathrm{CNT}$} & A3-1 & 56.9638 & 56.8322 & 0.1316 & \multirow{2}{*}{0.1279} & \multirow{2}{*}{47.0221} & \multirow{2}{*}{1.11} \\
\hline & A3-2 & 57.4587 & 57.3345 & 0.1242 & & & \\
\hline
\end{tabular}

Notes: density of nickel spray coating $8.90\left[\mathrm{~g} / \mathrm{cm}^{3}\right]$, density of aluminum spray coating $2.72\left[\mathrm{~g} / \mathrm{cm}^{3}\right]$, ${ }^{1)}$ relative to sprayed coatings of the aluminum or nickel without carbon materials 


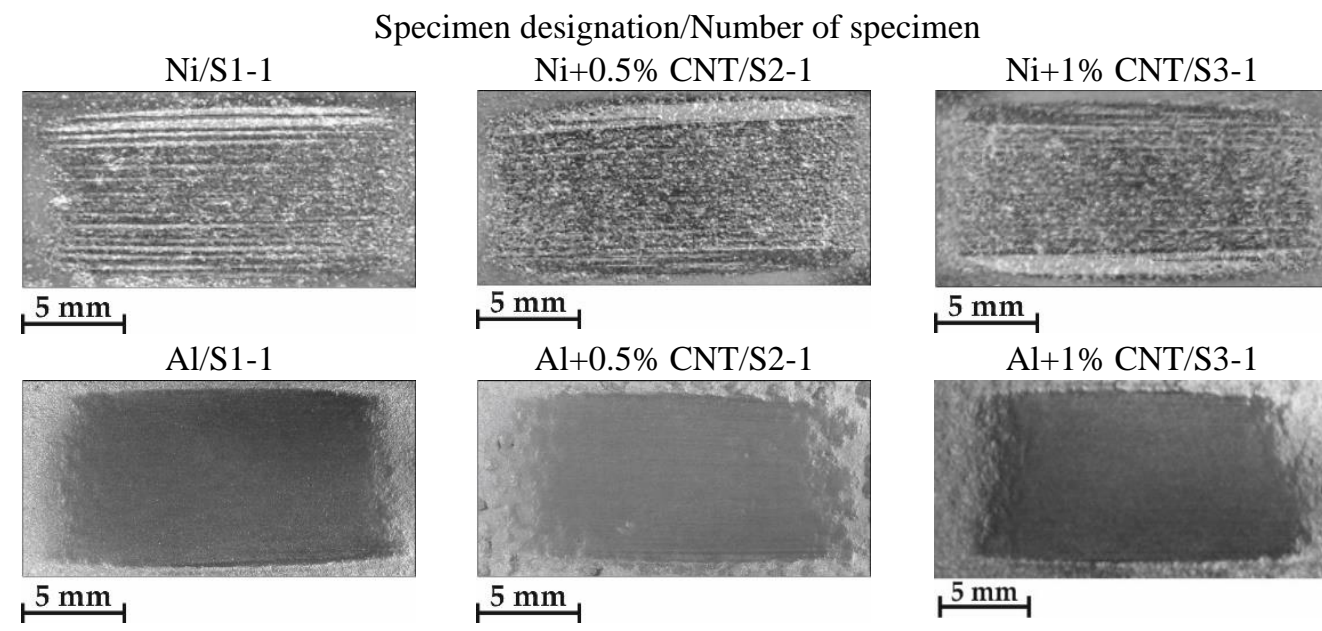

Fig.14. The surfaces of flame sprayed aluminum and aluminum with carbon nanotubes coatings after wear resistance metal-mineral tests

a)

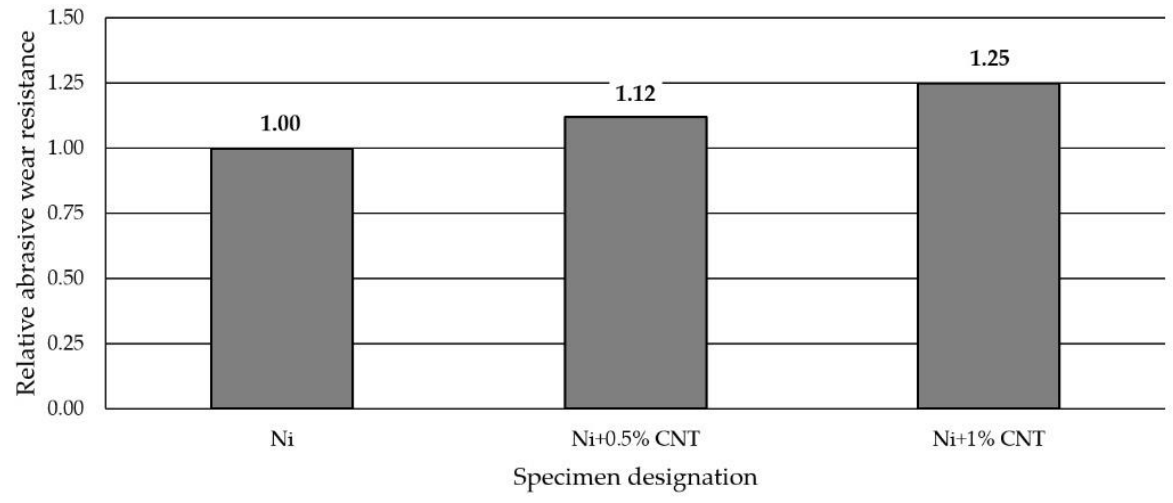

b)

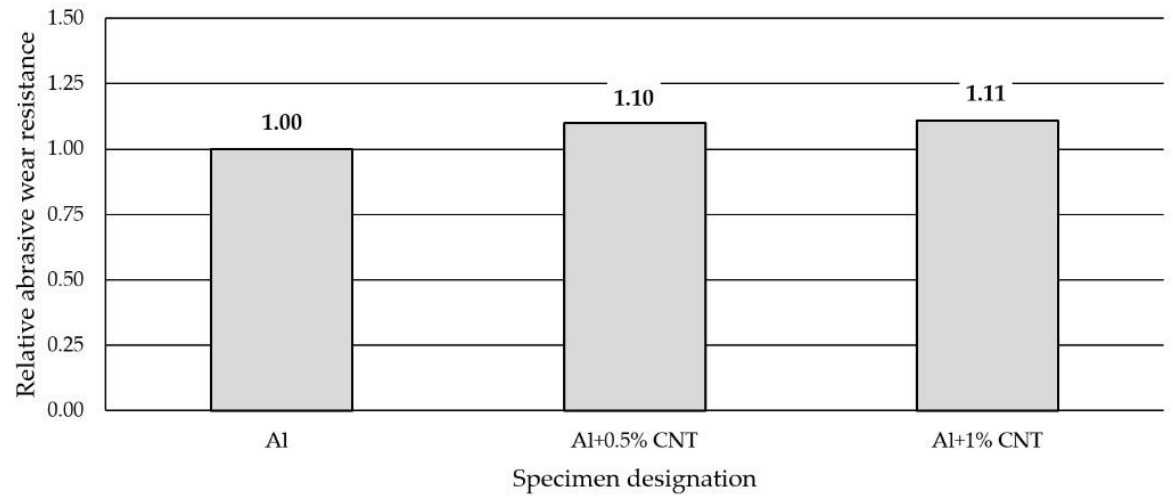

Fig. 15. Relative metal-mineral abrasive wear resistance (ASTM 65-00, procedure A) of flame sprayed metal matrix reinforced with carbon nanotubes coatings to pure metal coatings abrasive wear resistance

\section{DISCUSSION}

Visual and metallographic tests of the flame sprayed of nickel matrix and of aluminum matrix with carbon material reinforcement $(0.5$ wt.\% and 1 wt.\% of carbon nanotubes Nanocyl NC 7000) have shown that by using proper parameters of the process it is possible to receive coatings with acceptable quality level, characterized by proper adhesion to the substrate, lack of delamination and even thickness over the entire surface. The outer surface of the coatings was characterized by a mean roughness $(\mathrm{Ra})$ of not more than $10.2 \mu \mathrm{m}$, 
relatively low of porosity and was be free from cracks. During the flame spraying process, carbon material particles added to aluminum and also nickel did not oxidize completely in the oxyacetylene flame. Carbon nanotubes (melting point $4526{ }^{\circ} \mathrm{C}$ [42]) in the oxyacetylene flame have formed with aluminum Al-CNT type agglomerates, which due to the large volume and lower heat source temperature than other thermal spraying methods (oxyacetylene flame temperature $3160{ }^{\circ} \mathrm{C}$ [43]) migrated in large quantities to the coatings. Partially melted and partially only plasticized in a gas flame, Ni-CNT and Al-CNT agglomerates collided with the substrate at high speed, (Fig. 1b) and in this way formed a fine-grained coating structure. The difference between nickel and aluminum splats could be clearly observed. Powder flame spraying process (PFS) in comparison with, for example, plasma spraying, increases the probability of stopping carbon nanotubes (CNT) in flame sprayed composite coating with nickel matrix as well as aluminum matrix. The presence of carbon material in both aluminum coatings and nickel coatings is initially confirmed by metallographic microscopic tests, which revealed areas carbon nanotubes on specimens (Fig. 4, Al+0.5\% CNT and Ni+1\% CNT). The presence of carbon materials can be observed on the entire cross-section of the coating as well as on the outer surface. No cracks were found inside the Al-CNT composite coatings, but only the presence of individual cavities was observed. The local cracks inside the Ni-CNT coating were observed only in the case of nickel coatings with the addition of $1 \mathrm{wt} \%$ carbon nanotubes. The SEM micrographs showing the cross section of the coatings are shown in Fig. 5-10. The typical lamellar type structure of the coatings could be easily observed from these micrographs. The tests made using scanning electron microscope have shown the presence of some areas consisting small carbon materials inclusions.

The oxygen content in the nickel and aluminum coatings is the result of oxidation of the metal particles in the gas flame and the atmosphere. The oxygen content of the nickel coating may be caused by the fact that nickel reacts with water vapor in the gas flame, and as a result of this process, hydrogen and nickel oxide are formed. The addition of carbon materials to the aluminum powder causes the carbon to bind oxygen as a strong deoxidizer, which is why its presence was not found in composite coatings with aluminum matrix and carbon material reinforcement $[44,45]$. These results were confirmed by the use of more advanced research method, which is Raman spectroscopy. The first-order Raman spectra display two main peaks between 1200 and $1700 \mathrm{~cm}^{-1}$, as shown in Fig. 11a and 11b, which are characteristic features of carbon nanotubes [46]. The peak at around $1600 \mathrm{~cm}^{-1}$ is called graphitic or simply $\mathrm{G}$ band and is due to optical phonon mode with E $2 \mathrm{~g}$ symmetry associated with an in-plane stretching of sp 2-bonded carbon atoms. The peak at around $1350 \mathrm{~cm}^{-1}$ is called disorder-induced or D band and is not observed, for a single-crystal perfect graphite [47]. D mode is present in all graphite-like carbons and originates from structural defects. Therefore, the ratio of the G/D modes is conventionally used to quantify the structural quality of carbon nanotubes. Highquality nanotubes have this ratio significantly higher than 100. At a lower functionalisation of the nanotube, the G/D ratio remains almost unchanged.

The hardness measurements of the tested coatings were proceeded using standard ISO 6507. The measurements were made both on the top surface and the cross-section of the sprayed coatings. These tests showed that using addition of $0.5 \mathrm{wt} . \%$ and $1 \mathrm{wt} . \%$ carbon nanotubes to aluminum coating (553.8 HV 0.5) caused an increase in its hardness of $28.5 \mathrm{HV}$ 0.5 for the $0.5 \mathrm{wt} . \%$ of carbon nanotube reinforcement and by $72.5 \mathrm{HV} 0.5$ for $1 \mathrm{wt} . \%$ of carbon nanotube reinforcement. Addition of carbon nanotubes to aluminum increases the coating hardness by of $8.2 \mathrm{HV} 0.1$ for the $0.5 \mathrm{wt} . \%$ of carbon nanotube reinforcement and by 9.5 HV 0,1 for 1 wt.\% of carbon nanotube reinforcement (Fig. 14).

Erosive wear resistance test results have shown that the addition of carbon nanotubes to nickel powder and aluminum powder does not increase the erosive wear resistance of flame 
sprayed coatings. During these tests, the aluminum coatings with carbon nanotubes had worn out by erosion with large and small angles of erodent incidence more than nickel coatings with carbon nanotubes and much more than aluminum coatings without carbon materials reinforcement. It was observed that for all tested coatings erosive wear resistance was better during using smaller angle of erodent incidence [48] (table 5).

Among the nickel coatings the best metal-mineral type wear resistance had the nickel coating with $1 \%$ wt. CNT. The wear resistance of this coating was $25 \%$ higher than pure nickel coating. The nickel coatings with addition of $0.5 \mathrm{wt} . \%$ carbon nanotubes in comparison to pure aluminum coating had better relative wear resistance by $12 \%$ (table 6 ).

The metal-mineral type wear resistance the aluminum coating regardless of the nanotube content was about $11 \%$ higher than pure aluminum coating. The cause of decreasing wear of the nickel and aluminum coatings with carbon material addition was increased glide of ceramic abrasive particles on metal.

Based on the conducted study and the obtained results, it can be concluded that it is possible to introduce carbon particles in the form of carbon nanotubes (CNT) into the nickel matrix and also aluminum matrix by means of flame spraying method. The flame spraying is a more effective and cheaper alternative to other technologies surface treatment of metals. Properly selected parameters of the flame spraying process allow to preserve the properties of particles of carbon materials, their even distribution in the coating, proper bonding with the matrix and they prevent the effects of their thermal degradation. Additionally, the coatings are characterized by relatively high wear resistance $[15,16]$.

\section{CONCLUSIONS}

The analysis carried out comparing properties of flame sprayed nickel matrix coatings and also aluminum matrix coatings with the addition of carbon material reinforcement $(0.5 \mathrm{wt} \%$ and 1 wt.\% of Nanocyl NC 7000 carbon nanotubes) resulted in the following conclusions:

- Producing nickel coatings and aluminum coatings with the addition of carbon nanotubes reinforcement with high quality is possible when using flame spraying technology.

- In the nickel with 1 wt.\% carbon nanotubes reinforcement flame sprayed coating structure, the areas with a share of carbon less than 16 wt.\% were observed. In the aluminum coating with 1 wt.\% carbon nanotubes, similar areas were observed, with a share of carbon about $33 \mathrm{wt} . \%$.

- The addition of $1 \mathrm{wt} . \%$ carbon nanotubes to nickel powder resulted in increasing the hardness of flame sprayed coatings by over $11 \%(70 \mathrm{HV})$, while the same addition of carbon nanotubes to aluminum powder resulted in increasing the hardness of flame sprayed coatings increase of almost 13 percent (approx. $10 \mathrm{HV}$ ).

- The carbon nanotubes reinforced nickel and also aluminum flame sprayed coatings have lower erosive wear resistance than pure metal coatings with large and small angles of erodent incidence.

- The metal-mineral type wear resistance of flame sprayed nickel coatings reinforced with carbon nanotubes is $12 \%$ to $25 \%$ higher in comparison to pure nickel coating, while the same addition of carbon nanotubes to aluminum powder resulted in reducing the wear resistance of flame sprayed coatings by about $10 \%$ in comparison to pure aluminum coating. 


\section{REFERENCES}

1. Lisiecki, A., (2016). Comparison of Titanium Metal Matrix Composite surface layers produced during laser gas nitriding of $\mathrm{Ti}_{6} \mathrm{Al}_{4} \mathrm{~V}$ alloy by different types of lasers. Arch. Metall. Mater., 61, 1777-1783.

2. Rogalski, G., Świerczyńska, A., Landowski, M., Fydrych, D., (2020). Mechanical and microstructural characterization of TIG welded dissimilar joints between $304 \mathrm{~L}$ austenitic stainless steel and Incoloy 800HT nickel alloy. Metals, 10(5), 559.

3. Sajek, A. (2020). Welding thermal cycles of joints made of S1100QL steel by SAW and hybrid plasma-MAG processes. Adv. Mater. Sci., 20(4), 75-86.

4. Cacko, R., Chmielewski, T., Hudycz, M., Golański, D. (2020). New approach of friction AlN ceramics metallization with the initial FEM verification. Arch. Civ. Mech. Eng., 20(3), 1-11.

5. Pańcikiewicz, K., Świerczyńska, A., Hućko, P., Tumidajewicz, M. (2020). Laser dissimilar welding of AISI 430F and AISI 304 stainless steels. Materials, 13(20), 4540.

6. Szala, M., Łatka, L., Walczak, M., Winnicki, M., (2020). Comparative study on the cavitation erosion and sliding wear of cold-sprayed $\mathrm{Al} / \mathrm{Al}_{2} \mathrm{O}_{3}$ and $\mathrm{Cu} / \mathrm{Al}_{2} \mathrm{O}_{3}$ coatings, and stainless steel, aluminium alloy, copper and brass. Metals, 10(7), 856.

7. Sundaramoorthy, R., Tong, S.X, Parekh, D., Subramanian, C., (2017). Effect of matrix chemistry and WC types on the performance of $\mathrm{Ni}-\mathrm{WC}$ based MMC overlays deposited by plasma transferred arc (PTA) welding. Wear, 376-377, B, 1720-1727.

8. Rutkowska-Gorczyca, M., Ptak, A., Winnicki, M., (2020). Analysis of the tribological properties of $\mathrm{Cu}-\mathrm{aTiO}_{2}$ composite coatings applied by the cold spray method. Tribologia, 292(4) 51-57.

9. Czupryński, A., (2019). Flame spraying of aluminum coatings reinforced with particles of carbonaceous materials as an alternative for laser cladding technologies. Materials, 12(21), 3467.

10. Kumar, S., Ghosh, S. K. (2020). Porosity and tribological performance analysis on new developed metal matrix composite for brake pad materials. J. Manuf. Proc., 59, 186-204.

11. Takashi, I., (2006). Overview of trends in advanced composite research and applications in Japan. Adv. Compos. Mater., 15, 3-37.

12. Bokobza, L., (2007). Multiwall carbon nanotube elastomeric composites. A review. Polymer, 48, 4907-4920.

13. Curtin, W.A., Sheldon, B.W., (2004). CNT-reinforced ceramics and metals. Mater. Today, 7, 4449.

14. Saffar, K.P.A., Najafi, A.R., Moeinzadeh, M.H., Sudak, L.J.A., (2013). Finite element study of crack behavior for carbon nanotube reinforced bone cement. World J. Mech., 3, 13-21.

15. Bakshi, S.R., Singh, V., Balani, K., McCartney, D.G., Seal, S., Agarwal, A., (2008). Carbon nanotube reinforced aluminum composite coating via cold spraying. Surf. Coat. Technol., 202, $5162-5169$.

16. Keshri, A.K., Balani, K., Bakshi, S.R., Singh, V., Laha, T., Seal, S., Agarwal, A., (2009). Structural transformations in carbon nanotubes during thermal spray processing. Surf. Coat. Technol., 203, 2193-2201. 
17. Wu, Y., Kim, G., (2011). Carbon nanotube reinforced aluminum composite fabricated by semisolid powder processing. J. Mater. Process. Technol., 211, 1341-1347.

18. Liao, J., Tan, M., Ramanujan, R.V., Shukla, S., (2011). Carbon nanotube evolution in aluminum matrix during composite fabrication process. Mater. Sci. Forum, 690, 294-297.

19. Bakshi, S.R., Singh, V., Seal, S., Agarwal, A., (2009). Aluminum composite reinforced with multiwalled carbon nanotubes from plasma spraying of spray dried powders. Surf. Coat. Technol., 203, 1544-1554.

20. Zeng, X., Zhou, G., Xu, Q., Xiong, Y., Luo Ch., Wu, J., (2010). A new technique for dispersion of carbon nanotube in a metal melt. Mater. Sci. Eng. A, 527, 5335-5340.

21. Kondoh, K., Fukuda, H., Umeda, J., Imai, H., Fugetsu, B., Endo, M., (2010). Microstructural and mechanical analysis of carbon nanotube reinforced magnesium alloy powder composites. Mater. Sci. Eng. A, 527, 4103-4108.

22. He, X., Kitipornchai, S., Liew, K.M., (2005). Buckling analysis of multi-walled carbon nanotubes: A continuum model accounting for van der Waals interaction. J. Mech. Phys. Solids, 53, 303-326.

23. Tan, H., Jiang, L.Y., Huang, Y., Liu, B., Hwang, K.C., (2007). The effect of van der Waals-based interface cohesive law on carbon nanotube-reinforced composite materials. Compos. Sci. Technol., 67, 2941-2946.

24. Kelly, A., (2006). Composite materials after seventy years. J. Mater. Sci., 41, 905-912.

25. Łatka, L., Michalak, M., Jonda, E. (2019). Atmospheric plasma spraying of $\mathrm{Al}_{2} \mathrm{O}_{3}+13 \% \mathrm{TiO}_{2}$ coatings using external and internal injection system. Adv. Mater. Sci., 19(4), 5-17.

26. Musztyfaga-Staszuk, M., Czupryński, A., Kciuk, M. (2018). Investigation of mechanical and anticorrosion properties of flame sprayed coatings. Adv. Mater. Sci., 18(4), 42-53.

27. Jażdżewska, M., Bartmański, M. (2021). Nanotubular Oxide Layer Formed on Helix Surfaces of Dental Screw Implants. Coatings, 11(2), 115.

28. Mele, C., Bozzini, B., (2010). Localised corrosion processes of austenitic stainless steel bipolar plates for polymer electrolyte membrane fuel cells. J. Power Sources, 195 3590-3596.

29. Łatka, L., Michalak, M., Szala, M., Walczak, M., Sokołowski, P., Ambroziak, A., (2021). Influence of $13 \mathrm{wt} \% \mathrm{TiO}_{2}$ content in alumina-titania powders on microstructure, sliding wear and cavitation erosion resistance of APS sprayed coatings. Surf. Coat. Technol., 410, 126979.

30. Klimpel, A., Dobrzanski, L.A., Lisiecki, A., Janicki, D., (2005). The study of properties of Ni$\mathrm{W}_{2} \mathrm{C}$ and $\mathrm{Co}-\mathrm{W}_{2} \mathrm{C}$ powders thermal sprayed deposits. J. Mater. Process. Technol., 164, 10681073.

31. Winnicki, M., Baszczuk, A., Jasiorski, M., Małachowska, A., (2017). Corrosion resistance of copper coatings deposited by cold spraying. J. Therm. Spray Technol., 26, 1935-1946.

32. Mele, C., Lionetto, F., Bozzini, B., (2020). An erosion-corrosion investigation of coated steel for applications in the oil and gas field, based on bipolar electrochemistry. Coatings, 10(2), 92.

33. Czupryński, A., Górka, J., Adamiak, M., (2016). Examining properties of arc sprayed nanostructured coatings. Metalurgija, 55, 173-176. 
34. Adamiak, M., Czupryński, A., Kopyść, A., Monica, Z., Olender, M., Gwiazda, A., (2018). The properties of arc-sprayed aluminum coatings on armor-grade steel. Metals, 8, 142.

35. Lisiecki, A. Titanium Matrix Composite Ti/TiN Produced by Diode Laser Gas Nitriding. Metals, $2015,5,54-69$.

36. Szala, M., Łatka, L., Awtoniuk, M., Winnicki, M., Michalak, M., (2020). Neural modelling of APS thermal spray process parameters for optimizing the hardness, porosity and cavitation erosion resistance of $\mathrm{Al}_{2} \mathrm{O}_{3}-13 \mathrm{wt} \% \mathrm{TiO}_{2}$ coatings. Processes, 8(12), 1544.

37. Dobrzanski, L.A., Klimpel, A., Bonek, M., Lisiecki, A., (2003). Surface-layer's structure of X40CrMoV5-1 steel remelted and/or WC alloyed with HPDL laser. Mater. Sci. Forum, 437-4, 69-72.

38. Klimpel, A., Dobrzanski, L.A., Lisiecki, A., Janicki, D., (2006). The study of the technology of laser and plasma surfacing of engine valves face made of X40CrSiMo10-2 steel using cobaltbased powders. J. Mater. Process. Technol., 175, 251-256.

39. Laha, T., Agarwal, A., McKechnie, T., Seal, S., (2004). Synthesis and characterization of plasma spray formed carbon nanotube reinforced aluminum composite. Mater. Sci. Eng. A, 381, 249258.

40. Łatka, L., Biskup, P., (2020). Development in PTA surface modifications a review. Adv. Mater. Sci., 20(2), 39-53.

41. Tomków, J., Czupryński, A., Fydrych, D. (2020). The abrasive wear resistance of coatings manufactured on high-strength low-alloy (HSLA) offshore steel in wet welding conditions. Coatings, 10(3), 219.

42. Wei, X., Wang, M. S., Bando, Y., Golberg, D., (2011). Thermal stability of carbon nanotubes probed by anchored tungsten nanoparticles. Sci. Technol. Adv. Mater., 12, 1-6.

43. Czupryński, A., Górka, J., Adamiak, M., Tomiczek, B., (2016). Testing of flame sprayed $\mathrm{Al}_{2} \mathrm{O}_{3}$ matrix coatings containing $\mathrm{TiO}_{2}$. Arch. Metall. Mater., 61, 1363-1370.

44. Moreno-Soriano, R., Soriano-Moranchel, F., Flores-Herrera, L.A., Sandoval-Pineda, J.M., de Guadalupe González-Huerta, R., (2020). Thermal Efficiency of Oxyhydrogen Gas Burner. Energies, 13, 5526.

45. Mele, C., Bocchetta, P., Bozzini, B., (2017). Characterization of the particulate anode of a laboratory flow Zn-air fuel cell. J. Appl. Electrochem., 47, 877-888.

46. Tuinstra, F, Koenig, J.L., (1970). Raman spectrum of graphite. J. Chem. Phys. 53, 1126-1130. https://doi.org/10.1063/1.1674108.

47. Pimenta, M.A, Dresselhaus, G, Dresselhaus, M.S, Cancado, L.G., Jorio, A., Saito, R., (2007). Studying disorder in graphite-based systems by Raman spectroscopy. Phys. Chem. Chem. Phys., 9, 1276-1290.

48. Hejwowski, T., (2009). Erosive and abrasive wear resistance of overlay coatings. Vacuum, 83, $166-170$. 